\title{
Competence-specific Autolysis in Streptococcus sanguis
}

\author{
By DIANE HORNE† AND ALEXANDER TOMASZ* \\ The Rockefeller University, New York, USA
}

(Received 14 August 1984; revised 8 October 1984)

\begin{abstract}
Streptococcus sanguis strain Wicky activated to competence for genetic transformation is known to undergo a rapid decrease in optical density upon transfer to an alkaline buffer containing reducing agents. We studied the mechanism of this autolysis-like process and made the following observations. The process was specific because preincubation of the competence inducing factor with a specific inactivating protein prevented both cellular lysis and acquisition of competence for genetic transformation. The optical density decrease of competent bacteria involved the release of a large fraction of intracellular protein, RNA and lipid. However, no hydrolysis of phospholipid and no degradation of cell wall polymers including peptidoglycan could be detected. No peptidoglycan hydrolase activity capable of degrading radiolabelled $S$. sanguis cell walls was detected in unfractionated $S$. sanguis extracts. It is suggested that autolysis of competent $S$. sanguis involves the activity of a novel type of murein hydrolase that introduces only a limited number of bond breaks into the peptidoglycan.
\end{abstract}

\section{INTRODUCTION}

The widespread occurrence of cell wall degrading enzymes, autolysins, among bacteria and the phenomenon of autolysis have led to much speculation about the possible physiological roles and cellular control of these enzymes (Shockman et al., 1974; Tomasz \& Höltje, 1977; Tomasz, 1983). Such a control mechanism would be essential to maintain cellular integrity during those processes which are assumed to require localized and/or transient autolytic activity, i.e. cell wall turnover, separation of daughter cells following cell division (Rogers, 1970, 1981), and competence to undergo genetic transformation (Tomasz, 1969; Young et al., 1964; Akrigg et al., 1967). It has been proposed that one of the early events following interaction of cells with the competence (inducing) factors (Tomasz \& Hotchkiss, 1964; Pakula, 1965) in both the pneumococcal and streptococcal transformation systems is the triggering of limited murein hydrolase activity at the cell equator. The hydrolase, presumably rupturing relatively few covalent bonds to expose DNA binding sites, would not affect the structural integrity of the cell. On the other hand, lysis and rupture of the cell wall, which has already been weakened, may occur when these bacteria are exposed to conditions that promote autolysis such as exposure to hypertonic medium (Seto \& Tomasz, 1975) or postincubation in special media (Ranhand et al., 1971; Ranhand, 1973). The existence of competence-related lysis in $S$. sanguis is of particular interest since many strains of this bacterium (including strain Wicky) are naturally occurring penicillin-tolerant bacteria which do not undergo lysis during treatment with cell wall inhibitors (Horne \& Tomasz, 1980), and testing of $S$. sanguis extracts for murein hydrolase activity has yielded only negative results (Horne \& Tomasz, 1977). In this communication we describe studies on the autolysis of competent $S$. sanguis using bacteria selectively labelled with radioactive tracers in various cell components. Our data support the suggestion of Ranhand (1973) that the autolysis of competent $S$. sanguis involves breakage of a limited number of covalent bonds in the peptidoglycan.

† Present address: Department of Microbiology, Weber State College, Odgen, UT 84408, USA.

Abbreviations: AIF, activation inhibition factor; CF, competence factor; LTA, lipoteichoic acid; PG, peptidoglycan; PYG, proteose-peptone/yeast extract medium. 


\section{METHODS}

Bacterial cultures. Streptococcus sanguis strain Wicky was used in these studies since the bacteria are noncompetent for genetic transformation unless treated with exogenous competence factor (CF; Pakula, 1965). Stock cultures were prepared in brain heart infusion broth $\left(16 \mathrm{~h}, 37^{\circ} \mathrm{C}\right.$; Difco). The overnight culture was diluted 50-fold into an enriched chemically defined medium (Cden; Tomasz, 1966) buffered at pH 7.6 with $0.05 \mathrm{M}$-sodium phosphate buffer.

Reagents. Benzylpenicillin was purchased from Eli Lilly, Indianapolis, Ind., USA. The Chalaropsis muramidase was prepared by the method of Hash \& Rothlauf (1967). All other reagents were from commercial sources.

Transformation procedures. Cell-free extract derived from competent cultures of the related $S$. sanguis Challis strain grown in the proteose-peptone/yeast extract medium (PYG; Perry, 1968) was used as a source of CF; the cell-free filtrates were heated at $85^{\circ} \mathrm{C}$ for $15 \mathrm{~min}$ to remove a bacteriocin as described previously (Schlegel \& Slade, 1973; Horne \& Perry, 1974). Transforming DNA was prepared from a mutant of $S$. sanguis Challis that was resistant to $5 \mathrm{mg}$ streptomycin $\mathrm{ml}^{-1}$. The DNA was isolated according to the modified method of Young \& Spizizen (1961) using the C-phage associated lysin to rupture the cells (Fischetti et al., 1971).

Competence was induced in cultures of $S$. sanguis Wicky by adding the CF-containing filtrates $(20 \%$, by vol.). $\mathrm{CF}$ was added to $S$. sanguis Wicky growing exponentially in the Cden medium at a cell density of $2 \times 10^{7}$ c.f.u. $\mathrm{ml}^{-1}$ and competence developed after incubating the cultures at $37^{\circ} \mathrm{C}$ for $30 \mathrm{~min}$. Control noncompetent cultures were prepared by adding PYG medium in place of CF. Samples of $1 \mathrm{ml}$ were removed and exposed to the transforming DNA $\left(5 \mu \mathrm{g} \mathrm{ml}^{-1}\right)$ and the number of transformants was determined as described elsewhere (Horne \& Perry, 1974). The purification of the putative pneumococcal CF receptor, also known as the activation inhibitory factor (AIF), was as described previously (Horne et al., 1977b).

Biosynthetic labelling of the macromolecular components of cells. The radioactively-labelled precursors used in these studies were: $\left[{ }^{3} \mathrm{H}\right] \mathrm{glycerol}\left(5 \mathrm{Ci} \mathrm{mmol}^{-1} ; 1 \mu \mathrm{Ci}\right.$ and $10 \mu \mathrm{g}$ per ml of growth medium); $\left[{ }^{3} \mathrm{H}\right]$ acetic acid (sodium salt; $125 \mathrm{mCi} \mathrm{mmol}^{-1} ; 10 \mu \mathrm{Ci}$ and $\left.6.8 \mu \mathrm{g} \mathrm{ml}^{-1}\right)$; $\left[6{ }^{-3} \mathrm{H}\right] \mathrm{uracil}\left(20 \mathrm{Ci} \mathrm{mmol}^{-1} ; 2.5 \mu \mathrm{Ci}\right.$ and $\left.10 \mu \mathrm{g} \mathrm{m}^{-1}\right)$; $\mathrm{L}-\left[4,5-{ }^{3} \mathrm{H}\right]$ lysine $\left(60 \mathrm{Ci} \mathrm{mmol}^{-1} ; 1 \mu \mathrm{Ci}\right.$ and $\left.9 \mu \mathrm{g} \mathrm{ml}^{-1}\right)$; and $\mathrm{L}-\left[\right.$ methyl $\left.{ }^{-3} \mathrm{H}\right]$ methionine $\left(10 \mathrm{Ci} \mathrm{mmol}^{-1} ; 1 \mu \mathrm{Ci}\right.$ and $\left.15 \mu \mathrm{g} \mathrm{ml}^{-1}\right)$ [ $\left.1 \mathrm{Ci}=37 \mathrm{GBq}\right]$. All of these precursors were purchased from New England Nuclear. $N$-Acetyl-D-[1$\left.{ }^{3} \mathrm{H}\right]$ glucosamine $\left(\left[{ }^{3} \mathrm{H}\right] \mathrm{GlcNAc} ; 4.7 \mathrm{Ci} \mathrm{mmol}^{-1} ; 2 \mu \mathrm{Ci}\right.$ and $\left.0.1 \mu \mathrm{g} \mathrm{ml}^{-1}\right)$ was obtained from Amersham. Unless otherwise stated in the text, the radioactive precursor was added at a cell density of approximately $5 \times 10^{6} \mathrm{c} . \mathrm{f}$.u. $\mathrm{ml}^{-1}$ and kept in the medium throughout the period of competence development.

The amount of radioactivity lost from the cells during autolysis was measured as described previously (Horne $\&$ Tomasz, 1977). Cell-free supernatant fluids were prepared by removing the bacteria by centrifugation in a microcentrifuge $(12000 \mathrm{~g}, 10 \mathrm{~min})$. The label that was incorporated into macromolecular material was measured following precipitation with ice cold $10 \%(w / v)$ TCA. The amount of labelled lysine or GlcNAc incorporated into the peptidoglycan (PG) was assayed by the modified Park-Hancock fractionation procedure (Park \& Hancock, 1960; Horne \& Perry, 1974).

Biosynthetic labelling of cell walls. $\left[{ }^{3} \mathrm{H}\right] \mathrm{GlcN}$ Ac or $\left[{ }^{3} \mathrm{H}\right] \mathrm{lysine}$ was added to $20 \mathrm{ml}$ of an exponentially growing culture at a cell density of $10^{7}$ c.f.u. $\mathrm{ml}^{-1}$ and growth was continued for $2 \mathrm{~h}$. The bacteria were harvested by centrifugation and washed three times with distilled water. They were combined with cells from $200 \mathrm{ml}$ of nonlabelled culture and crude cell walls were isolated (Mosser \& Tomasz, 1970). Purified cell walls were obtained by extracting the crude cell walls with $2 \%$ (w/v) SDS at $80^{\circ} \mathrm{C}$ for $30 \mathrm{~min}$ followed by extensive washing.

Determination of peptidoglycan digestion. Various preparations of labelled cell walls were incubated with autolysed $S$. sanguis Wicky or with a heterologous murein hydrolase, the Chalaropsis muramidase. Cells were removed from crude autolysates by centrifugation $(10000 \mathrm{~g}, 10 \mathrm{~min})$. The test was done as follows: $10 \mu \mathrm{l}$ of a suspension of labelled cell walls $\left(0.3\right.$ to $1 \times 10^{4}$ c.p.m.) were mixed with $250 \mu$ l of autolysate or with $10 \mu l$ of the muramidase $\left(1 \mathrm{mg} \mathrm{ml}^{-1}\right)$ in $240 \mu \mathrm{l}$ sodium acetate buffer, pH 4.8 for $24 \mathrm{~h}$ at $37^{\circ} \mathrm{C}$. After incubation, $20 \mu \mathrm{l}$ of $30 \%$ $(w / v)$ formaldehyde and $20 \mu \mathrm{l}$ of $4 \%(w / v)$ bovine serum albumin solution were added and the undigested walls were pelleted by centrifugation at $12000 \mathrm{~g}(10 \mathrm{~min})$. Radioactivity released from the cell walls was measured by dissolving $200 \mu \mathrm{l}$ samples in Biofluor scintillation fluid (Beckman) and counting in a Mark II scintillation spectrometer (Nuclear Chicago).

Autolysis of $S$. sanguis Wicky. The lysing buffer $0.05 \mathrm{M}$-Tris(hydroxymethyl)methylaminopropanylsulphonic acid (TAPS)/0.02 M-2-mercaptoethanol/0.01 M-EDTA, pH 9.2 of Ranhand et al. (1971) was used. Competent and noncompetent cells were pelleted by centrifugation $\left(4000 \mathrm{~g}, 10 \mathrm{~min}, 4^{\circ} \mathrm{C}\right)$, washed twice in cold $0 \cdot 15 \mathrm{M}-\mathrm{NaCl}$ and resuspended in the original volume of distilled water. To initiate autolysis, the bacteria were diluted $1: 10$ into the lysing buffer and incubated at $37^{\circ} \mathrm{C}$. $\mathrm{OD}_{550}$ was determined at intervals ( $1 \mathrm{~cm}$ cuvettes). In some experiments, the crude autolysates were used to lyse suspensions of noncompetent cells in a manner similar to the assay for solubilization of labelled cell walls.

Lipid extraction and $T L C$. The bacterial lipids were extracted from $\left[{ }^{3} \mathrm{H}\right]$ acetate-labelled cells by the method of Ames (1968). TLC was done using the solvent system chloroform/methanol/water $(65: 25: 4$, by vol.) to develop the chromatograms (Horne et al., 1977a). Bands $0.5 \mathrm{~cm}$ wide were scraped into scintillation vials for measurement of radioactivity. 
$S D S-P A G E$. Cell-free extracts obtained from $\left[{ }^{3} \mathrm{H}\right]$ glycerol-labelled bacteria after autolysis $\left(2 \mathrm{~h}, 37^{\circ} \mathrm{C}\right)$ were dialysed and concentrated. The material was then applied to a $10 \%$ polyacrylamide gel. The method of Weber $\&$ Osborn (1969) was used for electrophoresis in the presence of SDS. The amount of radioactivity was determined in $1.2 \mathrm{~mm}$ slices of the gels as described earlier (Horne \& Tomasz, 1977).

\section{RESULTS}

\section{Autolysis of competent versus noncompetent $S$. sanguis Wicky}

Fig. 1 (a) illustrates autolysis of competent cells when resuspended in lysing buffer. Autolysis, detected as a decrease in the optical density of the cell suspension with time, appeared to be specific for the competent state. The decline in the optical density of noncompetent cells was much lower than that observed with the competent bacteria. The simultaneous addition of the pneumococcal competence activation inhibitory factor (AIF) along with CF prevented autolysis as well as inhibiting the development of competence.

AIF decreased the number of transformants by more than two orders of magnitude compared with cultures which were treated with CF alone (Fig. $1 a$, inset). Pretreatment with penicillin, which is known to trigger autolytic activity in many bacteria (Tomasz, 1979), did not stimulate autolysis of noncompetent cells (Fig. 1a).

\section{Loss of radiolabelled protein and RNA during autolysis}

There was a substantial release of intracellular, TCA-precipitable components during the course of autolysis in the competent cells (Fig. 1 b). Approximately $18 \%$ of the total protein was detected in the cell-free supernatant fluids after $30 \mathrm{~min}$ of incubation in the buffer (shown here with $\left[{ }^{3} \mathrm{H}\right]$ methionine-labelled bacteria). In the same time period only about $1 \%$ of the labelled protein was lost from noncompetent cells. Similar results were obtained for RNA labelled with $\left[{ }^{3} \mathrm{H}\right]$ uracil. After $2 \mathrm{~h}$ in lysing buffer, $30 \%$ of labelled RNA was detected outside the competent cells compared with only about $1 \%$ in the noncompetent bacteria. The total TCA-precipitable radioactivity declined during incubation in the lysing buffer; however, the decrease in precipitable counts was virtually identical in both types of cells (not shown).

Noncompetent cells lysed following suspension in a crude autolysate derived from competent cells. The loss of the intracellular markers occurred to about the same extent (data not shown). This finding is in accord with the report of Ranhand et al. (1971) who assumed that a soluble component was released by the autolysed bacteria and that the component was probably an enzyme since it was heat-labile.

Although the amount of the total cell RNA and protein lost from the cells was considerable, it was certainly not as much as the quantities released from bacteria undergoing autolysis due to extensive cell wall degradation. Ranhand et al. (1971) indicated that much of the cell wall remained intact and that only a limited amount of damage could be observed at the equatorial zone of the cells. We therefore attempted to determine if any cell wall-specific material was solubilized during autolysis.

\section{Assay for peptidoglycan degradation during autolysis of competent cells}

In order to detect possible cell wall damage, we utilized either $\left[{ }^{3} \mathrm{H}\right] \mathrm{GlcNAc}$ or $\left[{ }^{3} \mathrm{H}\right] \mathrm{lysine}$ as precursors of cell wall polymers. The former compound has been shown to be a specific label for the cell walls, being incorporated into PG and cell wall polysaccharide about equally (unpublished observations; Horne \& Perry, 1974). Lysine is incorporated into both protein $(80 \%)$ and PG $(20 \%)$ (Horne \& Perry, 1974). In these experiments, the bacteria were either continuously labelled with the precursor as described in Methods or subjected to a 15 min pulse followed by a chase period of one doubling time in unlabelled medium. During autolysis very little if any label was lost from cells labelled with $\left[{ }^{3} \mathrm{H}\right] \mathrm{GlcN}$ Ac or from the PG of cells labelled with $\left[{ }^{3} \mathrm{H}\right]$ lysine if the cells were continuously labelled (Table 1 , continuous labelling expts 1,2 and 3) or pulse-chased with $\left[{ }^{3} \mathrm{H}\right]$ GlcNAc (Table 1 , expts 4 and 5). The retention of the label suggested that the bulk of the cell wall remained intact during autolysis. In order to detect any selective degradation of newly made cell wall material, the bacteria were pulsed with GlcNAc during the last $15 \mathrm{~min}$ of competence induction before being placed in the lysing buffer. No digestion of the nascent cell wall material occurred (Table 1, expts 6 and 7). 

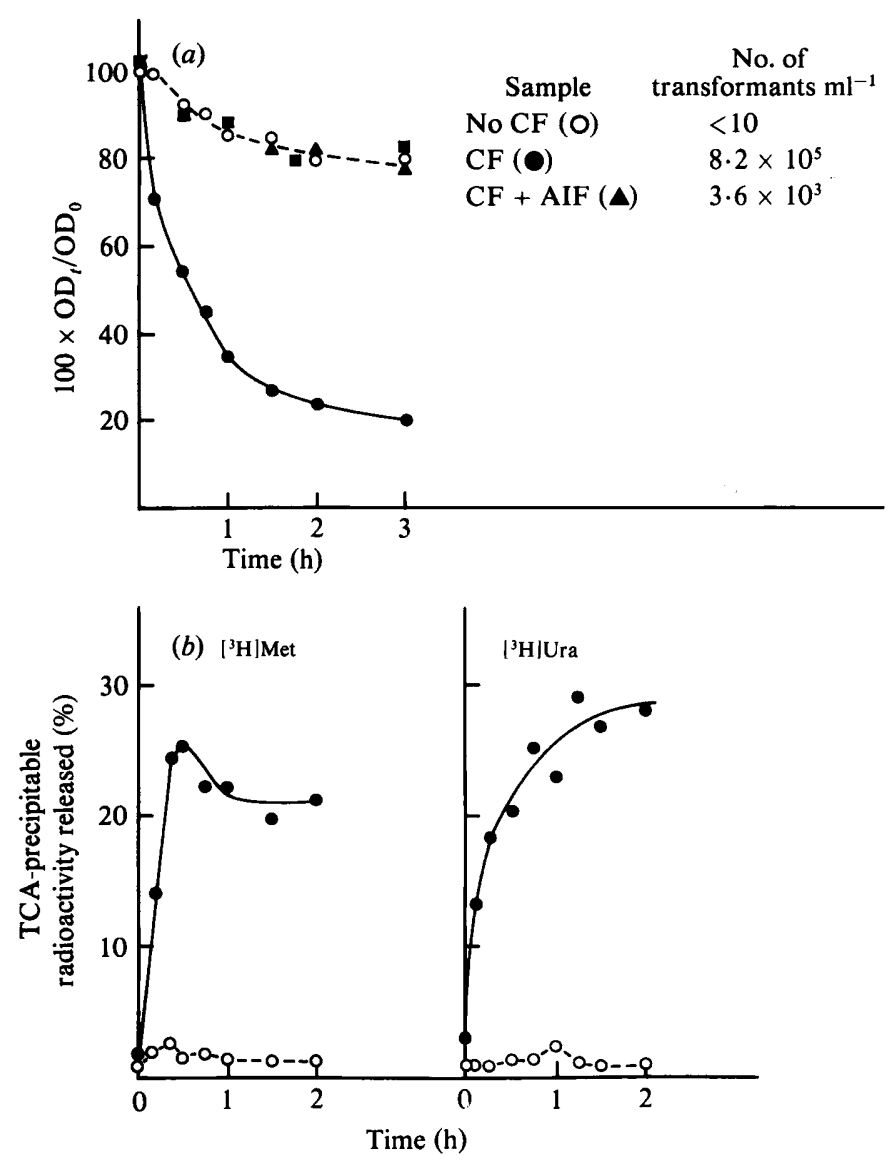

Fig. 1. Autolysis and release of intracellular macromolecular material from $S$. sanguis Wicky. Cells grown in Cden, pH 7.6, to a cell density of $2 \times 10^{7}$ c.f.u. $\mathrm{ml}^{-1}$ were treated with $20 \%$ (v/v) CF for $30 \mathrm{~min}$ at $37^{\circ} \mathrm{C}$ for development of competence. Control, noncompetent cultures were treated with the same volume of PYG or with benzylpenicillin $\left(0.5 \mu \mathrm{g} \mathrm{ml}^{-1}\right)$ for $45 \mathrm{~min}$ at $37^{\circ} \mathrm{C}$. (a) Autolysis of competent and noncompetent cell suspensions in lysing buffer. CF-treated competent cells ( $O$, solid lines); untreated noncompetent cells $(O$, dashed lines); cells treated simultaneously with $C F$ and $1.4 \mu \mathrm{g}$ pneumococcal AIF ml $\mathrm{m}^{-1}(\boldsymbol{\Delta}$, dashed lines); and cells pretreated with penicillin ( $\boldsymbol{\square}$, dashed lines). The inset indicates the number of transformants per $\mathrm{ml}$ obtained after $1 \mathrm{ml}$ of each culture was removed after competence induction and exposed to transforming DNA as described in Methods. $(b)$ Release of intracellular macromolecular components during autolysis. Cells were labelled with $\left[{ }^{3} \mathrm{H}\right]$ methionine $\left(\left[{ }^{3} \mathrm{H}\right] \mathrm{Met}\right)$ or with $\left[{ }^{3} \mathrm{H}\right]$ uracil $\left(\left[{ }^{3} \mathrm{H}\right] \mathrm{Ura}\right)$ before and during competence induction as described in Methods and subjected to autolysis. The cell-free TCA-precipitable c.p.m. were detected as described in the text. Competent cells ( $\odot$, solid lines); noncompetent cells $(O$, dashed lines). The percentage of the total TCA-precipitable material set free in competent versus noncompetent cells was as follows: $18 \%$ versus $1 \%$ with $\left[{ }^{3} \mathrm{H}\right]$ methionine-labelled cells and $30 \%$ versus $0.9 \%$ in $\left[{ }^{3} \mathrm{H}\right]$ uracil-labelled cells.

\section{Assay for peptidoglycan hydrolase activity in the autolysate of competent cells}

Purified cell walls radiolabelled with $\left[{ }^{3} \mathrm{H}\right] l y$ sine or $\left[{ }^{3} \mathrm{H}\right] \mathrm{GlcN}$ Ac were treated at $37{ }^{\circ} \mathrm{C}$ with cell-free extracts derived from autolysed competent cells. The release of radioactivity from the labelled cell walls in autolysate-treated samples was indistinguishable from that in control samples even after the prolonged incubation period $(18 \mathrm{~h}$; Table 2$)$. In contrast, the Chalaropsis muramidase digested a major portion of the cell wall-associated label.

\section{Assay for phospholipase activity during autolysis of competent cells}

The possibility that autolysis was mediated by damage to the cell membrane rather than to PG was considered. The possible involvement of a phospholipase associated with autolysis was 
Table 1. Lack of peptidoglycan degradation during autolysis of competent cells

Unless otherwise stated, bacteria were labelled with the radioactive precursors and subsequently fractionated by the standard procedures described in Methods.

\begin{tabular}{|c|c|c|c|}
\hline \multirow[b]{2}{*}{ Experiment } & \multirow[b]{2}{*}{ Fraction } & \multicolumn{2}{|c|}{ TCA-insoluble c.p.m. per $200 \mu \mathrm{l}$} \\
\hline & & Competent cells & Noncompetent cells \\
\hline $\begin{array}{l}\text { 1. Continuous } \\
\text { labelling } \\
{\left[{ }^{3} \mathrm{H}\right] \mathrm{GlcNAc}}\end{array}$ & $\begin{array}{l}\text { Total } \\
\text { Supernatant fluids }\end{array}$ & $\begin{array}{r}5070 \\
87\end{array}$ & $\begin{array}{r}4425 \\
63\end{array}$ \\
\hline $\begin{array}{l}\text { 2. Continuous } \\
\text { labelling } \\
{\left[{ }^{3} \mathrm{H}\right] \text { lysine }}\end{array}$ & $\begin{array}{l}\text { Total (A) } \\
\text { Total PG } \ddagger \text { (B) } \\
\text { Cell-asociated PG (C) } \\
\text { Cell-free PG (B-C) }\end{array}$ & $\begin{array}{r}6900 \\
2298 \\
2053 \\
245\end{array}$ & $\begin{array}{r}6090 \\
1952 \\
1367 \\
585\end{array}$ \\
\hline 3. As in 2 & $\begin{array}{l}\text { Total (A) } \\
\text { Total PG (B) } \\
\text { Cell-associated PG (C) } \\
\text { Cell-free PG (B-C) }\end{array}$ & $\begin{array}{r}5731 \\
1738 \\
1690 \\
48\end{array}$ & $\begin{array}{r}6085 \\
1912 \\
1610 \\
302\end{array}$ \\
\hline $\begin{array}{l}\text { 4. Pulse-chase* } \\
{\left[{ }^{3} \mathrm{H}\right] \text { GlcNAc }}\end{array}$ & $\begin{array}{l}\text { Total } \\
\text { Supernatant fluids }\end{array}$ & $\begin{array}{r}1330 \\
72\end{array}$ & $\begin{array}{r}1142 \\
75\end{array}$ \\
\hline 5. As in 4 & $\begin{array}{l}\text { Total } \\
\text { Supernatant fluids }\end{array}$ & $\begin{array}{r}1627 \\
30\end{array}$ & $\begin{array}{r}1450 \\
9\end{array}$ \\
\hline $\begin{array}{l}\text { 6. Pulset } \\
{\left[{ }^{3} \mathrm{H}\right] \mathrm{GlcN} A \mathrm{c}}\end{array}$ & $\begin{array}{l}\text { Total } \\
\text { Supernatant fluids }\end{array}$ & $\begin{array}{r}7560 \\
176\end{array}$ & $\begin{array}{r}8730 \\
93\end{array}$ \\
\hline 7. As in 6 & $\begin{array}{l}\text { Total } \\
\text { Supernatant fluids }\end{array}$ & $\begin{array}{r}12250 \\
478\end{array}$ & $\begin{array}{r}13536 \\
113\end{array}$ \\
\hline
\end{tabular}

* Bacteria were labelled with $2 \mu \mathrm{Ci}\left[{ }^{3} \mathrm{H}\right] \mathrm{GlcN} A c \mathrm{ml}^{-1}$ at a cell density of $10^{7} \mathrm{c}$.f.u. $\mathrm{ml}^{-1}$ for $15 \mathrm{~min}$ at $37^{\circ} \mathrm{C}$. The cells were then harvested by centrifugation, washed with medium three times and resuspended in prewarmed nonradioactive medium and incubated at $37^{\circ} \mathrm{C}$ for one generation time until competence induction. Competence was induced as described in Methods.

† Competent cells (cell density $3 \times 10^{7}$ c.f.u. $\mathrm{ml}^{-1}$ ) and noncompetent cells (see Methods) were labelled with $\left[{ }^{3} \mathrm{H}\right]$ GlcNAc $\left(2 \mu \mathrm{Ci} \mathrm{ml}^{-1}\right)$ for $15 \mathrm{~min}$ at $37^{\circ} \mathrm{C}$. The cells were then harvested and autolysed as described in Methods.

$\ddagger$ PG, peptidoglycan. Incorporation of the precursors into peptidoglycan was as described by Horne \& Perry (1974)

Table 2. Assay for peptidoglycan hydrolase activity in the autolysate of competent cells

The labelled cell walls were incubated with the preparations in the appropriate buffer for $18 \mathrm{~h}$ at $37^{\circ} \mathrm{C}$ and $200 \mu \mathrm{l}$ samples were examined. Assay for the solubilization of the cell walls is described in Methods.

\begin{tabular}{|c|c|c|c|c|c|}
\hline \multirow[b]{2}{*}{ Label } & \multirow[b]{2}{*}{ Treatment } & \multicolumn{2}{|c|}{ Crude cell walls } & \multicolumn{2}{|c|}{ Purified cell walls } \\
\hline & & Total c.p.m. & Released c.p.m.* & Total c.p.m. & Released c.p.m.* \\
\hline$\left[{ }^{3} \mathbf{H}\right]$ Lysine & $\begin{array}{l}\text { None } \\
\text { Muramidase } \\
\text { Autolysate }\end{array}$ & $\begin{array}{l}9000 \\
2600 \\
9000\end{array}$ & $\begin{array}{c}488(5 \cdot 4) \\
1700(65) \\
492(5 \cdot 5)\end{array}$ & $\begin{array}{l}5000 \\
2200 \\
5000\end{array}$ & $\begin{array}{c}60(1 \cdot 2) \\
1728(78) \\
121(2 \cdot 4)\end{array}$ \\
\hline$\left[{ }^{3} \mathrm{H}\right] \mathrm{GlcNAc}$ & Autolysate & 6000 & $124(2 \cdot 0)$ & 6000 & $78(1 \cdot 0)$ \\
\hline
\end{tabular}

investigated. The lipids of competent and noncompetent cells were labelled with $\left[{ }^{3} \mathrm{H}\right]$ acetate (95\% incorporated into lipid constituents; Horne et al., 1977a) before autolysis. Following autolysis of the competent cells, the total lipid was extracted from both competent and noncompetent cell suspensions and analysed by TLC. No alteration in the TLC patterns could be detected between the competent and noncompetent extracts (Fig. 2). Furthermore, no evidence of phospholipase activity was detected in either type of cell suspension. There was no evidence for a 'new' band migrating slower than peak I representing the phospholipids of $S$. sanguis strain Wicky, presumably phosphatidyl glycerol and cardiolipin (Horne et al., 1977a), nor was there any increase in the height of peak IV (neutral lipids) following incubation in lysing buffer (data not shown). 


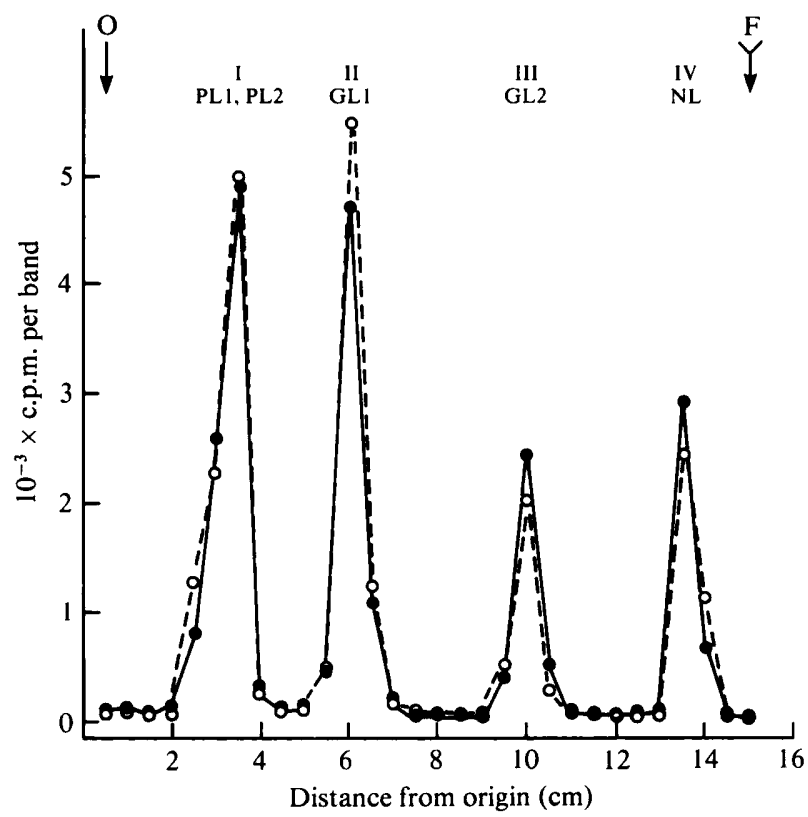

Fig. 2. TLC of $\left[{ }^{3} \mathrm{H}\right]$ acetate-labelled lipids extracted from autolysed $S$. sanguis Wicky. Lipid extracts from cell suspensions were developed in chloroform/methanol/water and the radioactivity in $0.5 \mathrm{~cm}$ bands was measured as described in the text. The arrows represent the origin $(O)$ and the solvent front (F). The four major peaks have been identified: I represents two phospholipids (PL1 and PL2); II and III represent glycolipids (GL1 and GL2) and IV represents neutral lipid (NL). Lipids of competent cells (O, solid lines) and noncompetent cells $(O$, dashed lines).

\section{Analysis of $\left[{ }^{3} \mathrm{H}\right]$ glycerol-containing cell components released during autolysis}

A significant portion of $\left[{ }^{3} \mathrm{H}\right]$ glycerol-labelled materials was lost from competent cells $(60 \%$ of total radioactivity) and a lesser amount from noncompetent cells $(26 \%$ of total) during autolysis $\left(2 \mathrm{~h}, 37^{\circ} \mathrm{C}\right)$. The radioactive precursor has been found to be incorporated into the membraneassociated polyglycerophosphate type of lipoteichoic acid (LTA) and the lipids in S. sanguis Wicky (Horne \& Tomasz, 1977). The material lost from the competent cells was analysed by SDS-PAGE (Fig. 3). The material containing $\left[{ }^{3} \mathrm{H}\right]$ glycerol was separated into two major types of constituents: region I, which represented the polyglycerophosphate polymer (deacylated and acylated forms of the polymer) and region II, which represented the lipids. About $15 \%$ of the total radioactivity applied to the gel was detected in peak I and $81 \%$ in peak II. Although the amount of released label was less in noncompetent cells, virtually the same pattern was obtained when the material was analysed by SDS-PAGE. $\left[{ }^{3} \mathrm{H}\right]$ Glycerol-labelled material derived from crude cell wall-membrane complexes analysed by the same methods gave a somewhat similar pattern : about $25 \%$ of the label was associated with region I and $70 \%$ with region II (data not shown). The electrophoretic profile of the $\left[{ }^{3} \mathrm{H}\right]$ glycerol-labelled components released during autolysis of competent cells was quite different from that of similarly labelled material secreted during treatment with benzylpenicillin. In the latter case, there appeared to be a somewhat selective release of the LTA as over $60 \%$ of the secreted material was associated with the slower migrating material and only $35 \%$ was detected in the lipid region (Horne \& Tomasz, 1977). The data presented here suggest the loss of fragments of the plasma membrane during autolysis and no enrichment for LTA over its relative proportion among the glycerol-containing components found within the cells.

\section{DISCUSSION}

Ranhand et al. (1971) observed that $S$. sanguis made competent for genetic transformation by treatment with CF lysed (as judged by the decrease of optical density) upon transfer of the cells 


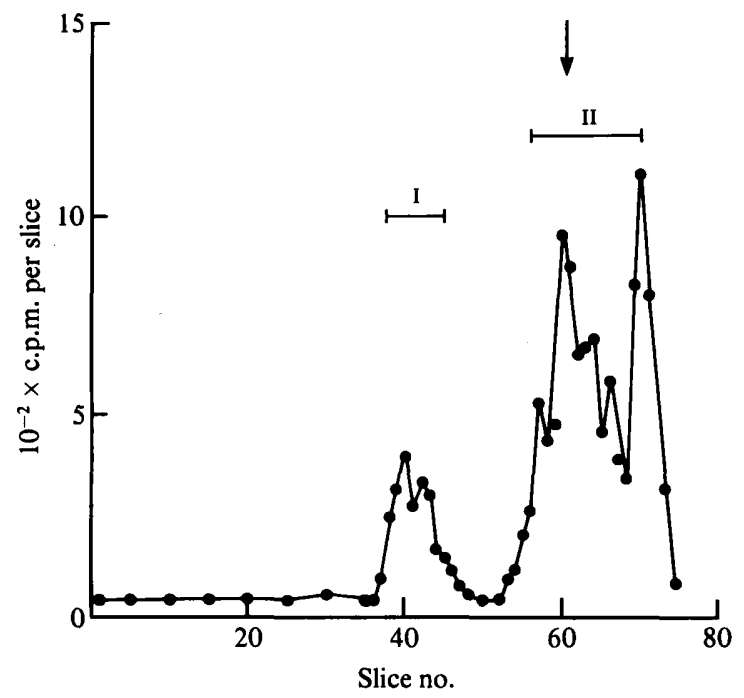

Fig. 3. SDS-PAGE of glycerol-labelled material released from competent cells after $2 \mathrm{~h}$ at $37^{\circ} \mathrm{C}$ in autolysis buffer. The bacteria and cell debris were removed by centrifugation from a $10 \mathrm{ml}$ competent culture, labelled with $\left[{ }^{3} \mathrm{H}\right]$ glycerol, and the resulting supernatant fluids were collected. The amount of labelled material released from competent cells amounted to $60 \%$ of the total versus $26 \%$ released in noncompetent cells. After extensive dialysis the material was subjected to SDS-PAGE, and the gels were sliced and measured for radioactivity as described in Methods. Two major types of components are indicated by the horizontal bars: I, LTA; II, the lipids. The arrow represents the position of the tracking dye.

to an alkaline buffer containing reducing agents. Susceptibility to lysis appeared to be specifically related to the competent state since only strains capable of genetic transformation exhibited lysis and conditions preventing induction of competence (e.g. inhibition of protein synthesis) also blocked lysis (Ranhand et al., 1971). We have confirmed and further extended the evidence for this specificity. Pretreatment with penicillin (instead of CF) did not induce autolysis of cultures. Low concentration of the AIF, a specific inhibitor and putative cellular receptor of CF (Horne et al., 1977b), inhibited both induction of competence and autolysis. Finally, cultures in which the level of competence was low also displayed low degrees of autolysis (undocumented observations).

We tried to define better the nature and mechanism of the decline in optical density of such bacterial suspensions. The possibility that lysis was the result of structural damage to the plasma membrane, followed by the escape of cytoplasmic material, was considered. Activation of a phospholipase during development of competence could conceivably be responsible for the observed autolysis. However, no phospholipase activity could be observed and there was no detectable qualitative or quantitative change in the phospholipids of autolysing cells (see Fig. 2). Similarly, no loss of PG could be detected from cells which were grown for several generations with radioactively labelled cell wall precursors and then allowed to lyse in the alkaline buffer. The possibility that lysis involved cell wall degradation restricted to the newly labelled portion of the PG was also tested. However, PG which had been synthesized just before autolysis during a short pulse with the radioactively labelled GlcNAc was not solubilized. Attempts to demonstrate murein hydrolase activity in vitro in cell-free preparations derived from autolysed cells and using radiolabelled strain Wicky cell walls as substrate were likewise negative, even though such cell-free autolysates did in fact lyse intact noncompetent cells.

Our experiments with radioactively labelled bacteria indicate that the decrease in the optical density of competent cultures was accompanied by a parallel release of a substantial fraction of 
protein, nucleic acid and lipid label. This process differed from the secretion of LTA and other material previously described in penicillin-treated $S$. sanguis (Horne \& Tomasz, 1979). While the penicillin-induced secretion was restricted to cell surface components (Horne \& Tomasz, 1977), the material lost during lysis of competent cells included intracytoplasmic protein and nucleic acid and the high degree of selectivity for LTA-release characteristic of the penicillintreated cells was not apparent during lysis of competent cells.

We interpret the escape of cytoplasmic markers as an indication of structural damage to the cell wall. This interpretation is in accord with that of Ranhand et al. (1971) who could only demonstrate limited disruption of the cell surface in electronmicroscopic thin sections of lysing $S$. sanguis. There are two intriguing aspects to this hydrolase activity. First, it seems to be limited enough not to cause solubilization of wall polymers. A mechanistically analogous cell wall 'nicking' has been proposed as the cause of 'non-lytic death' in certain groups of streptococci during treatment with cell wall inhibitors (Horne \& Tomasz, 1977; Tomasz, 1979).

A second interesting aspect of the autolysis is the apparent specific relationship to the competent state. It is interesting that lysis of both the competent $S$. sanguis and the pneumococcus seems to occur by wall disruption at the cellular equator. This area also represents the growth zone of cell wall (Briles \& Tomasz, 1970; Cole, 1965) and it has been suggested that the uptake of DNA molecules may also occur within this part of the bacterial surface (Tomasz et al., 1971). The nature of cell wall hydrolysing activity operating at this vital and dynamic surface site remains to be identified.

This work has beeen supported by a grant from the US Public Health Service, AI 16794.

\section{REFERENCES}

AKrigg, A., AYAD, S. R. \& BARKer, G. R. (1967). The nature of a competence-inducing factor in Bacillus subtilis. Biochemical and Biophysical Research Communications 28, 1062-1067.

AMES, G. F. (1968). Lipids of Salmonella typhimurium and Escherichia coli: structure and metabolism. Journal of Bacteriology 95, 833-843.

Briles, E. B. \& TOMASZ, A. (1970). Radioautographic evidence for equatorial wall growth in a Grampositive bacterium. Journal of Cellular Biology 47, 786-790

COLE, R. M. (1965). Bacterial cell wall replication followed by immunofluorescence. Bacteriological Reviews 29, 326-344.

Fischetti, V. A., Gotschlich, E. C. \& Bernheimer, A. W. (1971). Purification and physical properties of group C streptococcal phage-associated lysin. Journal of Experimental Medicine 114, 1105-1117.

Hash, J. H. \& Rothlauf, M. V. (1967). The N,Odiacetylmuramidase of Chalaropsis species purification and crystallization. Journal of Biological Chemistry 242, 5586-5590.

Horne, D. \& Perry, D. (1974). Effect of competence induction on macromolecular synthesis in a group $\mathrm{H}$ streptococcus. Journal of Bacteriology 118, 830-836.

HoRne, D. \& Tomasz, A. (1977). Tolerant response of Streptococcus sanguis to beta lactams and other cell wall inhibitors. Antimicrobial Agents and Chemotherapy 11, 888-896.

Horne, D. \& Tomasz, A. (1979). Release of lipoteichoic acid from Streptococcus sanguis: stimulation of release during penicillin treatment. Journal of $\mathrm{Bac}^{-}$ teriology 137, 1180-1184.

HORNE, D. \& TOMASz, A. (1980). Lethal effect of a heterologous murein hydrolase on penicillin-treated Streptococcus sanguis. Antimicrobial Agents and Chemotherapy 17, 235-246.
Horne, D., Hakenbeck, R. \& Tomasz, A. (1977a). Secretion of lipids induced by inhibition of peptidoglycan synthesis in streptococci. Journal of Bacteriology 132, 704-717.

Horne, D., Plotch, S. \& Tomasz, A. (1977b). Cell surface components implicated as attachment sites for the pneumococcal competence activator. In Bacterial Transformation and Transfection - Proceedings of the Third European Meeting on Genetic Transformation, pp. 11-34. Edited by A. Portoles. Amsterdam: North Holland.

Mosser, J. L. \& Tomasz, A. (1970). Choline-containing teichoic acid as a structural component of the pneumococcal cell wall and its role in sensitivity to lysis by an autolytic enzyme. Journal of Biological Chemistry 245, 287-298.

Paxula, R. (1965). Production of competence-provoking factor and development of competence of a transformable streptococcus in serum free media. Canadian Journal of Microbiology 11, 811822

Park, J. T. \& Hancock, R. (1960). A fractionation procedure for studies of the synthesis of cell-wall mucopeptide and of other polymers in cells of Staphylococcus aureus. Journal of General Microbiology 22, 249-258.

PerRY, D. (1968). Transformability of streptomycinresistant group H streptococci. Journal of Bacteriology 95, 132-138.

Ranhand, J. M. (1973). Autolytic activity and its association with the development of competence in group $\mathrm{H}$ streptococci. Journal of Bacteriology 115, 607-614.

Ranhand, J. M., Leonard, C. G. \& Cole, R. M. (1971). Autolytic activity associated with competent group H streptococci. Journal of Bacteriology 106, 257-268. 
ROGERS, H. J. (1970). Bacterial growth and the cell envelope. Bacteriological Reviews 34, 194-214.

Rogers, H. J. (1981). Some unsolved problems concerned with the assembly of the walls of Grampositive organisms. In Beta-Lactam Antibiotics, pp. 87-100. Edited by M. R. J. Salton \& G. D. Shockman. New York: Academic Press.

Schlegel, R. \& Slade, H. D. (1973). Properties of a Streptococcus sanguis (group $\mathrm{H}$ ) bacteriocin and its separation from the competence factor of transformation. Journal of Bacteriology 115, 655-661.

Seto, H. \& Tomasz, A. (1975). Protoplast formation and leakage of intramembrane cell components: induction by the competence activator substance of pneumococci. Journal of Bacteriology 121, 344353.

Shockman, G. D., Daneo-Moore, L. \& Higgins, M. L. (1974). Problems of cell wall and membrane growth, enlargement and division. Annals of the New York Academy of Sciences 235, 161-197.

Tomasz, A. (1966). Model for the mechanism controlling the expression of competent state in pneumococcus culture. Journal of Bacteriology 91, 1050-1061.

Tomasz, A. (1969). Some aspects of the competent state in genetic transformation. Annual Review of Genetics 3, 217-232.

Tomasz, A. (1979). The mechanism of the irreversible antimicrobial effects of penicillins: how the betalactam antibiotics kill and lyse bacteria. Annual Review of Microbiology 33, 113-137.
Tomasz, A. (1983). Murein hydrolases - enzymes in search of a physiological function? In The Target of Penicillin, pp. 155-163. Edited by R. Hakenbeck, J. V. Höltje \& H. Labischinski. Berlin: Walter de Gruyter.

TomasZ, A. \& HöltJE, J. V. (1977). Murein hydrolases and the lytic and killing action of penicillin. In Microbiology-1977, pp. 209-215. Edited by J. D. Schlessinger. Washington, DC: American Society for Microbiology.

Tomasz, A. \& HoTchkiss, R. D. (1964). Regulation of the transformability of pneumococcal cultures by macromolecular cell products. Proceedings of the National Academy of Sciences of the United States of America 57, 480-487.

TomasZ, A., ZanATI, E. \& Ziegler, R. (1971). DNA uptake during genetic transformation and the growing zone of the cell envelope. Proceedings of the National Academy of Sciences of the United States of America 68, 1848-1852.

WEBER, K. \& OSBORN, M. (1969). The reliability of molecular weight determinations by dodecylsulfate. Journal of Biological Chemistry 244, 4406-4412.

Young, F. E. \& SPIZIzEN, J. (1961). Physiological and genetic factors affecting transformation of Bacillus subtilis. Journal of Bacteriology 81, 823-829.

Young, F. E., TIPPER, D. J. \& STrominger, J. L. (1964). Autolysis of cell walls of Bacillus subtilis; mechanism and possible relationship to competence. Journal of Biological Chemistry 239, 3602-3660. 